\title{
Basic Kanji Learning Strategy using the Mnemonic and Happyou Methods in Japanese Literature Program Faculty of Social Sciences and Humanisties of Pakuan University
}

\author{
Rina Fitriana \\ \{mazayasyana@gmail.com\} \\ ${ }^{1}$ Faculty of Social Sciences and Humanisties of Pakuan University, Indonesia
}

\begin{abstract}
The strategy of learning Kanji with the Mnemonic method is one solution to eliminate this perception. These Kanji lectures were conducted by group presentation in which each group of students presented $8-10$ Kanji characters in every meeting. The research was conducted for 2 semesters with first and second semester students as subjects. The samples of study were A Class with 34 students. The book used was Minna no Nihongo Shokyuu Kanji I Eigoban with 220 basic kanji. The method author use in this study is a true experimental. These research subjects using two classes: A class consisting of 34 students which is an experimental class and class B are 34 students who are class control. An average pre-test score are 79 for experimental class and 77.5 for control class, while the value of post-test for experimental class is 89 and for the control class is 71 .
\end{abstract}

Keywords: mnemonic, happyou, association, loci , word markers

\section{Introduction}

Kanji letter expressing the meaning established by mimicking the shape of the object or the signs given in denoting an object or nature or jobs or other signs. Kanji is the script with pictographs system as it's base (Iwabuchi, 1989: 63). Kanji is formed of lines or stroke that can be counted. The number of lines or strokes of kanji called kakusuu, which can reach a dozen strokes. In a kanji letter, there is a section of character that shows the kanji meanings. That kanji portion is called bushu. Some kanji have the same bushu, so by classifying them we can identify the meanings of kanji. Kanji has seven types of bushu, namely (1) hen, (2) tsukuri, (3) kanmuri, (4) ashi, (5) tare, (6) nyoo, and (7) kamae (Katoo, 1991: 222).

Foreign students who learn Japanese generally finds it difficult to mastering kanji. Moreover, Japanese writing system using 3 types of letter. There is kanji, hiragana, and katakana. Hiragana and katakana are generally not a problem for foreign learners as it consists of 46 letters and only has one kind of way to read, so easily memorized without using a special method. In contrast to kanji, which one kanji generally have more than one way of reading, which is Chinese reading (onyomi) and Japanese reading (kunyomi). For example, this kanji \{男\} read as “dan" and “nan” for it's onyomi, while it's kunyomi is “otoko".

Considering there are thousands of kanji used in Japan, memorizing every possible way to read kanji is not an easy thing. However, memorizing how to write kanji is even harder. 
This is due to stroke numbers of writing kanji is varies, most of it has a lot of strokes. For example, kanji like \{機\} which requires only one hiragana \{き\} both have the same sound " $k i$ ", but to write it into kanji, requires 16 strokes. It makes memorizing each kanji require special methods in order to strengthen students memory.

Kanji I and II is a basic kanji course which aims to introduce a Japanese font that has an important role to support two language skills, the ability to write and read. Kanji subjects also have a very important role in supporting other subjects, particularly subjects that require writing and reading skills. Those subjects such as dokkai (reading comprehension), bunpou (grammar), and sakubun (writing).

Until now, the method used by the majority of basic kanji lecturer (Kanji I and Kanji II), particularly in Pakuan University Faculty of Social Sciences and Humanities Japanese Literature program still conventional, like teaching how to write and read each kanji based on textbook. The students are required to memorize how to write kanji characters without the methods which can simplify the process of memorization. This resulted in a decent memory of the students to write kanji, means that the ability of students in mastering kanji is not optimal. By not fully mastering kanji writing make students less confident in writing kanji. In addition, lecturers are still applying teacher center learning that make students feel bored in kanji class. It also resulted in the declining interest of students towards kanji subjects. The decreasing interest towards kanji, leads to a low-grade achievement which makes students fail and have to repeat the course next year.

Based on the results of interviews regarding kanji learning for 15 students who repeated kanji I and II courses, all answered that they were only able to remember kanji for short term, like when the course lasted or just one day, the next day was very difficult to remember even imagine how to write kanji that has been learned. In addition, interviews with the same questions were also conducted on 15 students who passed the kanji I and kanji II examinations, most of them answered that learning kanji requires routine writing exercises every day and it's time-consuming because if they lack on their routine training, they will easily forget how to write the kanji.

Pursuant to the problems experienced by students in learning kanji as authors have described above, the authors conclude the need to use new methods in teaching kanji, using the mnemonic method by using happyou (presentation) is needed. With this method, author will look at how the student's ability to remember kanji writing changes and how to increase student confidence in writing kanji.

\section{Literature Review}

The word "Mnemonic" comes from the Greek, "Mnemosyne" (remembrance 'memory'), which means Goddess of Memory. In his blog, Sunarwan says, mnemonic is memorize something with help of another object. Such assistance may be acronym, presupposition with objects, or "linking" (remembering something based on a relationship with something else). There are three basic principles when using mnemonic, which is imagination, association, and location. Based on these definitions can be said that the mnemonic is a technique to make it easier to remember something. More specifically, mnemonic means doing something by make a statement or expression, or linking words, ideas, and fantasies.

According to Jensen (2002), a mnemonic is a method to help remember the large amount of information that involves three elements: coding, maintenance, and recall. By applying 
some mnemonic techniques to remember something of information, recalling memory process will be easier because mnemonic always uses the principle of association (link) with something else. Such techniques, as follows:

1. Loci (Loci Method)

Loci is a mnemonic tool that serves to associate places or objects at known locations with things that want to be remembered. Usually, the use of these methods involve areas as visual memory then remember everything that was in place to connect each part so that it becomes an integral / combined intact. And everything from the venue contains any decree anything we want to remember or memorize.

2. Word Marker

Word marker system is a mnemonic tool to associate/connect one word with another word through an action or picture it using concrete objects. Word marker system is very helpful in remembering numbers. Said marker can be words we create our own or words that are already known to the public.

3. Link-word

Link-word techniques used to remember foreign words or abstract concepts. Link-word is another linking technique which associate words verbally and visually, the word that is sound similar or a concept that related to the word you want to be remembered.

4. Acronyms (Mnemonic Acronym System)

Acronym is how to remember a word by using every first letter of a group of words (sentences) into a new word. Usually, the use of acronyms is helpful when we want to remember words that need to be particularly ordered.

5. Chunking

This technique is commonly used to memorize numbers, although it also can be used to remember everything. Because our memory has such limited capacity, it is difficult for most people to learn a long series of numbers. However, if it can be placed in a number of pieces, the number is easier to remember. The theory is, rather than memorize eight digits simultaneously, it is better to divide the figures into several parts.

\section{Research Methods}

The method author use in this study is a true experimental. A true experimental is an experiment that tight control of the variables that affect and determine the sample with random system and uses the control class as a comparison, while the experimental class is a class who received treatment (Anwar, 2004). These research subjects using two classes: A class consisting of 34 students which is an experimental class and class B are 34 students who are class control. Experimental class is a class that is getting treatment of learning kanji using the new method, the method of mnemonic presentation using happyou (presentation), while Class $\mathrm{B}$ is the class that serves as a control, the class does not get treatment study using mnemonic and happyou, but use the lecture method that it's idea or notion of learning is determined by the teacher. 


\section{Discussion}

Learning strategy by using mnemonic methods in kanji I and II courses is the development of basic kanji learning strategy in Pakuan University Faculty of Social Sciences and Humanities Japanese Literature program. The aim of using this new strategy is to give students an easy and interesting impression towards kanji course that is usually considered as a difficult and tedious subject.

In the first 3 class meeting, the class presented in the form of a lecture by the teacher. At the first class meeting, the teacher tells the origin or history of how kanji were formed, along with other things that must be considered when studying the kanji. At the second and third meetings, teachers provide an overview of the basic kanji which often comes as a part of another kanji, which later will be used as the object of a presentation by students. Those kanji introduced in this second meeting are kanji which has a similar shape to the original object, such as (日, 月, 火, 水, 木, 金, 土, 山, 川, 田, 人, 目, 口,耳,). At the third meeting, teachers introduce kanji of numbers from 1 to 10 . The aims of this kanji orientation and introduction are to (1) stimulate students to be interested in kanji, (2) make students have a clear picture to analyze how to easily memorize kanji. At the fourth meeting onwards, students began to make a presentation group in turn.

In this course, students are given an opportunity for creative thinking and imagining on how to write kanji, and then the results shall be presented in the classroom. The audience students are given the opportunity to ask questions and express their opinions if the presenter's imagination is quite inappropriate. This presentation format is intended to make students have the confidence to present and defend the results of their creative thinking and imagination in front of other students. This study uses 220 basic kanji contained in the book Minna no Nihongo Shokyuu Kanji I Eigoban as the material object.

Based on the results of student presentations during the two semesters, the author can classify an easy way students remember writing kanji as follows:

1. Associating kanji elements with katakana

Some elements of kanji have a shape similar to the katakana. Therefore, students are looking for one easy way to remember writing kanji by associating kanji elements with katakana. Kanji element that resembles katakana that appear in basic kanji are as follows:

イ (i), エ (e), オ (o), カ (ka), ク (ku), ケ (to), シ (shi), セ (se), タ (ta), ト (to), ナ (na), ヌ (nu), ネ(ne), ノ(no), 八 (ha), ヒ (hi), マ (ma), ム (mu), メ (me), ヨ (yo), リ (ri) ロ (ro).

Table 1. Kanji element with katakana

\begin{tabular}{lllll}
\hline Kanji & $\begin{array}{c}\text { Kanji elements } \\
\text { associated with } \\
\text { katakana }\end{array}$ & How to read & How to remember & Meaning \\
\hline 右 (U8) & ナ+ロ & Migi & Na ro & Right \\
左 (U8) & ナ+エ & Hidari & Na e & Left \\
外 (U8) & タ +ト & Soto & Ta to & Out \\
友 (U9) & ナ+ヌ & Tomo & Na nu & Friend \\
多 (U13) & タ タ & Oo $(i)$ & Ta ta & Many \\
名 (U14) & タ ロ & Na $/$ mei & Ta ro & Name \\
etc. & & & & \\
\hline
\end{tabular}


For example, an easy way to remember みぎ (右) kanji which means 'right', students associate with ナロ katakana, so to write みぎ kanji, students just need to remember katakana naro. Similarly, ひだり (左) kanji which means 'left' is a combination of katakana ナ and 工, to write it just remember katakana nae, そと (外) which means 'outside', a combination of katakana 夕 and ト, to write it just remember katakana tato.

2. Associate the kanji part with surrounding objects

As the author mentions beforehand in the introductory chapter, that kanji character has kanji elements (bushu) which can help identify the meaning of the kanji. However, because some of those kanji element names are difficult to memorized and understood by freshmen, then the kanji elements names are converted by associate it to surrounding objects with similar shape.

Table 2. Kanji part that associated with surrounding object

\begin{tabular}{|c|c|c|}
\hline $\begin{array}{l}\text { Bushu } \\
\text { shape }\end{array}$ & Bushu name & Replacement name \\
\hline П & Kamae: dogamae & A cage with its door open \\
\hline 口 & Kamae: kunigamae & A cage with its door closed \\
\hline 門 & Kamae: mongamae & Gate \\
\hline ウ & Kanmuri: Ukanmuri & Pot Lid \\
\hline+ & Kanmuri: Kusa Kanmuri & Grass \\
\hline 广 & Tare: Midare & Shop 1 \\
\hline 庐 & Tare: Yamaidare & Shop 2 \\
\hline $\begin{array}{l}\text { 乃 } \\
\text { etc. }\end{array}$ & Tsukuri: oozatozukuri & Letter B \\
\hline
\end{tabular}

By using the new names as a replacement name that was created by the students as in Table 2, it will be easier for them to memorize how to write kanji. For example, to remember the 花 (はな) kanji which means 'flower', students will be given the bushu kusakanmuri which changed its name to the grass and katakana $イ$ (i) and $ヒ$ (hi), so it will be pronounced as 'grass ihi'. Another example, to remember the writing かん (漢) kanji consisting of 13 strokes, the students could dissect a kanji consists of 'mizu' renamed 'water', bushu kusakanmuri which was renamed 'grass', 口 meaning 'mouth' 二 meaning 'two', and 人 meaning 'person', so it will be pronounced to be 'on the left is water, on the top is grass, below that a mouth and two people'. Examples of how to dissect kanji above, more details can be seen on the following table.

Table 3. How to dissect kanji

\begin{tabular}{lll}
\hline Kanji & Kanji Elements & How to Remember \\
\hline 花 & \# (grass)イ (i) ヒ (hi) & Grass $i h i$ \\
漢 & ; ロニ 人 & $\begin{array}{l}\text { Water on left, grass on top, underneath a mouth and } \\
\text { two people' }\end{array}$ \\
\hline
\end{tabular}

3. Associate kanji elements with other kanji

This technique can make remembering kanji easier. By remembering the kanji element, students are able to remember some other kanji. If the student has been considering how to 
write kanji element, then they will easily remember how to write some other kanji that have the same element, such as the example in Table 4.

Table 4. Kanji element with other kanji

\begin{tabular}{|l|l|}
\hline Kanji Elements & Kanji that could be remembered \\
\hline 門 & 間, 聞, 開, 閉 \\
\hline 言 & 話, 読, 語 \\
\hline 車 & 軽, 転, 運 \\
\hline etc. & \\
\hline
\end{tabular}

Based on Table 4 it can be concluded that by memorizing one kanji element, students are

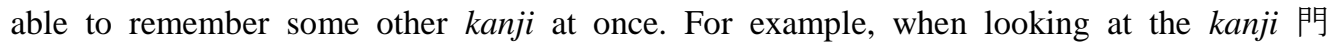
students will be reminded of how to write some other kanji that has the same elements, such as あいだ (間) kanji which means 'between', 聞く(きく) kanji which means 'to hear', 開ける (あける), which means 'to open', 閉める (しめる), which means 'to close'.

Learning activities by mnemonic method and presentation using the presentation made by the students in the experimental class (class A) showed very positive results, it proved in the average value of pre-test and post-test. An average pre-test (with the material presented at the first 3 class) are 79 for experimental class and 77.5 for control class, while the value of posttest for experimental class is 89 and for the control class is 71 . Based on the average value of pre-test and post-test, the ability of the experimental class student proved to have a lot of enhancement.

Based on the results of questionnaires obtained from research subjects, which is experimental class students, all of them enjoy learning using mnemonic method and happyou (presentation). Especially when they find an easy way to remember kanji and present it in the class, the good response from other students and teachers they received, seemingly to foster students curiosity and make them continue looking for an easy way on how to remembering kanji writing that has not been studied.

\section{Conclusion}

Based on the study above, it can be concluded that the basic kanji learning strategy uses mnemonic methods and happyou (1) are very effective as alternative ways to easily memorize how to write kanji, (2) make students think creatively and actively to find an easy way on how to remember kanji, (3) help maintain a longer span of memory (long term memory), (4) make students used to express and defend their opinions in front of many people, (5) boost the Japanese language ability, especially the ability to write and read, and (6) eliminates the presumption that kanji course is a very difficult and tedious subject, but it is actually an easy and interesting subject.

\section{References}

[1] Araya, Maki. Minna no Nihongo Shokyuu I Kanji I eigoban (Tokyo: 3A Corporation, 2000)

[2] Azwar, Saifuddin. Metode Penelitian (Jogjakarta: Pustaka Pelajar, 2004)

[3] Jensen, Eric. Otak Sejuta Gigabyte (Bandung:Alfabcta,2002) 
[4] Nur, Muhammad. Strategi-strategi Belajar (Surabaya:UNESA,2004)

[5] Sudjianto\&Ahmad Dahidi. Pengantar Linguistik Jepang (Bekasi:Kesaint Blanc, 2004)

[6] Sugiono. Metode penelitian Kuantitatif dan $R \& D$ (Bandung:Alfabeta,2011)

[7] Takebe, Yoshiake. Kanji wa Muzukashikunai (Tokyo:Aruku, 1998)

[8] Tamamura, Nihongo Kyouiku, Moji Goi no Kyoujuhou (Japan: Aruku, 2004)

[9] http://dwitantosunarwn.blogspot.com/2015/01/normal-0-false-false-false-en-us-x-none.html 